\title{
Upcoming events on EU issues
}

7th annual EU-Israel international seminar - 'Old Wounds - New Realities'

Foundation for European Progressive Studies, the Fondation Jean Jaurès and the KarlRenner-Institut

12-13 February 2022 (Tel Aviv)

Barcelona Workshop on Global Governance 2022

EsadeGeo (Esade Business School's Center for Global Economy and Geopolitics) and IBEI Institut Barcelona d'Estudis Internacionals (IBEI)

17-18 February 2022 (Barcelona/Online)

NextGenerationEU - Europe's Recovery Plan One Year On

ERA - Academy of European Law

22-23 February 2022 (Online)

Annual Conference on European Company Law and Corporate Governance 2022

ERA - Academy of European Law

10-11 March 2022 (Trier/Online)

War and Peace in the 21st Century "A Global Discussion on Strategic Autonomy: the EU and the Transformation of International Politics"

CIDOB in collaboration with EsadeGeo, with the support of "la Caixa" Foundation and the institutional board members

12 March 2022 (Barcelona)

Annual Conference on EU Law in the Pharmaceutical Sector 2022

ERA - Academy of European Law

17-18 March 2022 (Brussels/Online)

Annual Conference on European Environmental Law 2022

ERA - Academy of European Law

17-18 March 2022 (Trier/Online)

Annual Conference on White-Collar Crime in the EU 2022

ERA - Academy of European Law

17-18 March 2022 (Trier/Online) 
Annual Conference on European Data Protection Law 2022

ERA - Academy of European Law

24-25 March 2022 (Brussels/Online)

Annual Conference on European Labour Law 2022

ERA - Academy of European Law

24-25 March 2022 (Trier/Online)

Annual Conference on European Public Procurement Law 2022

ERA - Academy of European Law

31 March - 1 April 2022 (Trier/Online)

Annual Conference on Artificial Intelligence (AI) Systems and Fundamental Rights

ERA - Academy of European Law

7-8 April 2022 (Brussels/Online)

International Conference on Europeanization and European Union

World Academy of Science, Engineering and Technology

21-22 April 2022 (Boston)

New global challenges amid incomplete and divergent recoveries

BIS, BoE, ECB \& IMF

27-28 April 2022

Annual Conference on European Direct Taxation Law 2022

ERA - Academy of European Law

28-29 April 2022 (Trier/Online)

Annual Conference on European Patent Law 2022

ERA - Academy of European Law

5-6 May 2022 (Online)

Annual Conference on European Succession Law 2022

ERA - Academy of European Law

5-6 May 2022 (Trier/Online)

The State of the Union

EUI-European University Institute

5-7 May 2022 (Florence)

Annual Conference on European Immigration Law 2022

ERA - Academy of European Law

12-13 May 2022 (Brussels)

Annual Conference on European Social Security Law 2022

ERA - Academy of European Law

19-20 May 2022 (Trier/Online) 
2022 EUSA 17th Biennial Conference

European Union Studies Association

19-21 May 2022 (Miami)

FISA 2022 - EURADWASTE '22

French Presidency of the Council of the EU and the European Commission

30 May - 3 June 2022 (Lyon)

EU Green Week 2022

European Commission

30 May - 5 June 2022 (Brussels/Online)

Annual Conference on European Media Law 2022

ERA - Academy of European Law

2-3 June 2022 (Brussels/Online)

11th Biennial Conference of the ECPR Standing Group on the European Union

Luiss University

8-10 June 2022 (Rome)

Empirical Investigations in Services Trade Fourth Biennial Conference

The Trade Policy Research Network, Robert Schuman Centre for Advanced Studies, TEDU-TRC \& World Trade Institute

13-14 June 2022 (Ankara)

16 th Annual Conference of the Association for the Study of Sport and the EU

Association for the Study of Sport and the European Union

16-17 June 2022 (Lausanne)

Predicting Migration: Challenges, Opportunities and Policies

ITFLOWS Project

21-22 June 2022 (Brussels/Online)

ECB Forum on Central Banking

European Central Bank

27-29 June 2022 (Sintra)

28th International Conference of Europeanists "The Environment of Democracy"

Council for European Studies

20-22 June 2022 (Virtual sessions)

29 June - 1 July 2022 (Lisbon)

Annual Conference on EU Border Management 2022

ERA - Academy of European Law

7-8 July 2022 (Warsaw/Online)

UACES 52nd Annual Conference 2022

UACES

5-8 September 2022 (Lille) 
International Conference on Europeanization, Westernization and EU

World Academy of Science, Engineering and Technology

16-17 September 2022 (Rome)

International Conference on Europeanization and European Union

World Academy of Science, Engineering and Technology

20-21 September 2022 (Paris)

Annual Conference on European Family Law 2022

ERA - Academy of European Law

23-23 September 2022 (Trier)

Annual Conference on European Asylum and Migration Law 2022

ERA - Academy of European Law

29-30 September 2022 (Trier/Online)

Annual Conference on Law and Financial Innovation 2022

ERA - Academy of European Law

29-30 September 2022 (Trier/Online)

Annual Conference on Countering Terrorism in the EU 2022

ERA - Academy of European Law

6-7 October 2022 (Trier/Online)

Annual Conference on European State Aid Law 2022

ERA - Academy of European Law

20-21 October 2022 (Trier/Online)

Annual Conference on EU Law in the Insurance Sector 2022

ERA - Academy of European Law

27-28 October 2022 (Trier/Online)

Annual Conference on EU Criminal Justice 2022

ERA - Academy of European Law

17-18 November 2022 (Barcelona)

Annual Conference on European VAT Law 2022

ERA - Academy of European Law

17-18 November 2022 (Trier/Online)

Annual Conference on European Copyright Law 2022

ERA - Academy of European Law

24-25 November 2022 (Trier/Online)

Current Reflections on EU Anti-Discrimination Law

ERA - Academy of European Law

5-6 December 2022(Trier/Online) 
Annual Conference on EU Competition Law 2022

ERA - Academy of European Law

8-9 December 2022 (Trier/Online)

$\underline{\text { International Conference on Europeanization, Westernization and EU }}$

World Academy of Science, Engineering and Technology

9-10 December 2022 (London)

Compiled by

Concepció Muñoz Ruiz

European Documentation Center (UAB)

conxi.munoz@uab.cat 